\title{
Novinky v regulaci účetnictví a auditu v Evropské unii: novely zákonů o účetnictví a auditu v České republice
}

\author{
Vážení čtenáři,
}

období krizí bývá vždy hybatelem změn v oblasti regulace a ne jinak je tomu i v oblasti účetnictví a auditu v Evropské unii. S nevelkým časovým rozestupem dospěla Evropská unie k zásadním změnám jak ve směrnici upravující účetní závěrku (schválena 26. června 2013), tak i směrnici regulující provádění auditu (schválena 16. dubna 2014). Změny, které obě směrnice představují $\mathrm{v}$ daných oblastech, jsou v řadě ohledů zásadní a jsou výsledkem dlouhé diskuse a vyjednávání mezi orgány Evropské komise, Evropským parlamentem, zástupci odborné veřejnosti a profesními organizacemi, které trvalo několik posledních let a bylo odstartováno, jak již bylo zmíněno, finanční a hospodářskou krizí po roce 2008.

Nové směrnice stanovují lhůtu pro jejich začlenění do národních právních systémů členských zemí Evropské unie a pro Českou republiku znamenají novelu zákona o účetnictví a zákona o auditu. Rád bych se na tomto místě stručně zmínil alespoň o hlavních principech novel uvedených směrnic a o způsobu jejich implementace do uvedených zákonů.

\section{Směrnice Evropského parlamentu a Rady o ročních účetních závěrkách 2013/34/EU, o ročních účetních závěrkách, o konsolidovaných účetních závěrkách a souvisejících zprávách některých forem podniků}

Tato zcela nová směrnice představuje spojení dosavadní 4. směrnice Rady o ročních účetních závěrkách některých forem společností (78/660/EHS) a 7. směrnice Rady o konsolidovaných účetních závěrkách (83/349/EHS) do jediné směrnice, čímž původní směrnice zanikají. Obsahem a pozadím tvorby nové směrnice o účetních závěrkách se podrobněji zabývá např́íklad Žárová (2013) ${ }^{1}$.

Implementace nové směrnice proběhla v průběhu roku 2014 př́ípravou novely zákona o účetnictví, jejímž zpracovatelem bylo Ministerstvo financí České republiky. Na rozdíl od zkušeností $\mathrm{s}$ prŕípravou obdobných novel zákona o účetnictví a jeho prováděcích předpisů v minulosti, je nutno konstatovat, že proces př́pravy zmiňované novely o účetnictví probíhal ze strany ministerstva financí velmi efektivně, konstruktivně a v těsné spolupráci s odbornou veřejností. Tato potěšující skutečnost je také výstižně zmíněna $v$ důvodové zprávě ${ }^{2} \mathrm{k}$ předkládané novele:

„Návrh novely zákona o účetnictví byl pravidelně konzultován s odbornou veřejností $v$ rámci pracovni skupiny pro účetnictví jmenovanou paní náměstkyní ministra financí, sekce daně a cla. Členy této pracovní skupiny jsou, kromě zástupců Ministerstva financí, významni odborníci v oblasti účetnictví. Jedná se o zástupce akademické obce (děkan Fakulty financí a účetnictví a člen Katedry finančního účetnictví a auditingu Vysoké škole ekonomické v Praze), vicepresident Mezinárodní federace účetních, předseda Výboru pro účetni výkaznictvi Komory auditoru České republiky, předseda odborného kolegia Sekce účetnictví Komory daňových poradců České republiky, vedouci sekceneziskových organizací

\footnotetext{
Žárová, M.: Zlepši nová účetní směrnice účetni výkaznictví v Evropě? Český finanční a účetní časopis, 2013, roč. 8, č. 3, s. 4-5.

2 Viz Di̊vodová zpráva k návrhu novely zákona č. 563/1991 Sb., o účetnictví, část 11 - Závěrečná zpráva $z$ hodnoceni dopadi regulace.
} 
Komory daňových poradců České republiky, členka výboru Komory certifikovaných účetních, auditor - člen výboru pro veřejný sektor Komory auditorů České republiky a sekční ředitel Ekonomické sekce Ministerstva obrany. “

Práce na novele zákona o účetnictví byly zahájeny přípravou „seznamu“ potřebných úprav a ideového záměru či alternativ jejich legislativního řešení. V druhém kroku byly postupně eliminovány ty alternativy, které nezískaly v odborné diskusi dostatečnou podporu, a následně bylo na základě zvolených variant připraveno konkrétní řešení jednotlivých úprav zákona ve formě textu navrhované novely. Takto připravená novela zákona pak prošla standardním připomínkovým řízením, po kterém byla předána ke schválení vládě a dalšímu postupu do parlamentu. Předpokládaná účinnost novely je pro účetní závěrky počínající 1. lednem 2016 a později.

Podrobnější analýzou obsahu jednotlivých částí novely zákona o účetnictví a jejich teoretickým zdůvodněním se budu zabývat v článku v některém z dalších čísel tohoto časopisu.

\section{Směrnice Evropského parlamentu a Rady 2014/56/EU, kterou se mění směrnice 2006/43/ES o povinném auditu ročních a konsolidovaných účetních závěrek}

Novela směrnice o povinném auditu je završením dlouhého procesu, který započal v říjnu 2010 vydáním Zelené knihy obsahující 38 koncepčních otázek na téma možných změn v oblasti regulace auditu v EU, které by reagovaly na finanční a hospodářskou krizi (Green Paper Audit Policy: Lessons from the Crisis). Tato novela směrnice je navíc doprovázena Nařízením o auditu subjektů veřejného zájmu.

Práce na novele stávajícího zákona o auditorech v ČR, který byl schválen v roce 2009, ještě nezačaly, protože jim předchází ještě právě probíhající proces schvalování „malé“, tzv. technické novely zákona, který je aktuálně (listopad 2014) projednáván v parlamentu ČR.

Přesto, že konkrétní obsah novely zákona o auditorech představující implementaci novelizované směrnice Evropské unie o povinném auditu ještě není znám, lze podstatu novely shrnout do následujících hlavních oblastí:

- povinná rotace auditorských společností každých 10 let;

- sdílený audit jedné účetní závěrky více auditory;

- stanovení kritérií pro účast auditorů ve výběrových řízeních na audit účetní závěrky;

- zavedení seznamu služeb, které auditor nesmí poskytovat;

- zavedení limitu na výši honoráře za nepovolené služby;

- posílení role výborů pro audit zřizovaných auditovanými účetními jednotkami.

Stejně jako $\mathrm{v}$ prrípadě novely zákona o účetnictví budou podrobnější analýzu obsahu jednotlivých částí novely zákona o auditorech obsahovat nepochybně články $\mathrm{v}$ některém $\mathrm{z}$ dalších čísel tohoto časopisu, jakmile bude text novely připraven.

doc. Ing. Ladislav Mejzlík, Ph.D.

děkan

Fakulta financí a účetnictví

Vysoká škola ekonomická v Praze 